\title{
1 \\ The (Im)Mobility of Merantau as a Sociocultural Practice in Indonesia
}

\author{
Noel B. Salazar
}

Anthropology has developed greatly, as a discipline, through the study of (small) island societies. Many early anthropological interpretations, however, focused on internal processes so exclusively that inter-island exchange networks were easily overlooked. However, conceptions of both 'other' and 'self', as well as notions of 'travel' and 'home', have stemmed from these mobile interactions (Tagliacozzo 2009). Like places or locations more generally, 'home' is not conceptualized as fixed and static but as being generated through various and often messy relations between people and places (cf. Green 2013). As various chapters in this volume show, movement often involves place-making. On the islands of Vanuatu, for example, trees are a widespread symbol of stability, while canoes, like any other means of transport, index motion. The metaphorical image of crafting canoes out of trees captures the idea that movement can help to gain social stability (Bonnemaison 1984). Similarly, in insular Southeast Asia, the boat has traditionally been a metaphor for the 'ordered social group'. The boat metaphor, in Indonesia in particular, refers to an 'oceangoing society' but also a 'disciplined' and 'hierarchical' social system that is necessary for 'safety and great mobility' (Wolters 1999: 180).

Indonesia is an archipelago of more than six thousand inhabited islands in Asia Pacific, at the crossroads of Southeast Asia and Oceania. Its scattered geography has been conducive to mobility between, and beyond, the islands, including complex systems of circular movements and various forms of migration and cross-cultural 
mixing. While local mobilities are indigenous rather than a result of foreign contact (Bedford 1973; Chapman and Prothero 1985), the abundance of valuable natural resources meant that the Indonesian archipelago became a particularly important long-distance trade hub from at least the seventh century BCE. In addition to traders and itinerant merchants, people travelled to escape conflicts, in search of work, following their loved one(s) or religious beliefs. In this chapter, I explore the widespread occurrence of various forms of mobility between and beyond the Indonesian islands, and such mobilities communicate about imaginaries of 'home' and practices of belonging. ${ }^{1}$

Today, many Indonesians are engaged in a combination of short and temporary, as well as long-term and long-distance, travels, driven by both sociocultural and economic motivations. It is important to place these contemporary movements in the context of a long history of (im)mobility. ${ }^{2}$ Some of these mobilities have been explained as a cultural characteristic (Tirtosudarmo 2009). In this chapter, however, it becomes clear that the factors determining a 'culture of mobility' are highly complex and variable (cf. Salazar 2010b). It takes a number of forms, both over time and in different places, including internal, regional and transnational movements. It cuts across gender, class and skill boundaries, and exists in widely different demographic contexts. I argue that translocal movements among people with limited mobility resources are highly mediated, not only by regulations and brokers but also by 'modern' technologies. This assemblage of elements has changed the relation between people and places, nearby and further (and further) away, and the 'relative location' (Green 2013) of the 'homeland' and the envisioned return to it within the patterns of mobility in which people engage.

\section{Moving Histories}

Mobility is part of people's life experience across much of the Indonesian archipelago (Tirtosudarmo 2009). ${ }^{3}$ As historian Adrian Vickers argues, 'the element of mobility is the starting point of a critical social history of Indonesia' (2004: 305). The original populations of the islands were sparse and, by necessity, geographically mobile. In the precolonial period, trade and other interactions were conducted via inter-island routes. Not all movement was long-distance or by sea. Shifting cultivators, too, were accustomed to resettling in search of new land, which was abundant (Vickers 2004). The entire 
archipelago was a borderless space where constant exchanges took place. A certain 'wanderlust' has been ascribed to particular ethnic groups such as the Bugis, Minangkabau, Boyanese and Banjarese. Even those groups usually regarded as being more sedentary (e.g., the Balinese) have histories of migration and movement.

The arrival of foreign traders further expanded mobility in the region. The different patterns, directions and motivations of movement became severely affected by colonialism. Mobilities intensified and new forms were introduced, particularly state-sponsored migration and contract work. For the Dutch colonial administration, however, sedentary communities were a political, economic and social ideal. From the nineteenth century onwards, the household, village, land survey, census, map and school were among the technologies of rule used to control people's movements (Lowe 2003). Control of the coasts and seas was also important in this regard. The free and unrestricted (semi-)nomadic wanderings of peoples posed serious problems to the colonizers' bureaucracy. These movements subverted the controlling mechanisms of the state that had been erected to mediate contacts and commerce among locals. Nevertheless, some groups in the region chose to remain mobile because this had significant economic (trade), social (status) and political (independence) advantages.

The postcolonial Indonesian state continued its policies along similar lines. Anna Tsing (1993), for instance, describes the attempts of the Indonesian state to control the nomadic Meratus hill peoples of Kalimantan. The Meratus are migratory hunter-gatherers, who live in constantly changing kinship units, and who are widely dispersed. Indonesian officials tried to concentrate the Meratus in planned villages near the main roads. The implicit goal was to create a fixed, concentrated population. Meratus' immobility was the precondition of state supervision and development, whereas much of the identity of the Meratus as a people depended on 'unhampered mobility' (Tsing 1993: 41).

In general, strong mobility traditions throughout the archipelago pattern contemporary movements and form the basis of more recent labour migration. The travels of the Bugis and Makassar peoples of South Sulawesi are among the best known examples. The Bugis took to the sea in the fifteenth and sixteenth centuries, mainly to escape from the dominance of the Dutch East India Company in their homeland. In so doing, they became one of the most important maritime communities in the region. Bugis ships sailed to the northern coast of Australia, where cave paintings, Aboriginal loanwords and archaeological waste attest to their presence today (Tagliacozzo 2009). In 
the eighteenth century, they began establishing pioneer settlements around the archipelago, enabling the more or less permanent migration of Bugis settlers (while retaining political ties to the 'home' community) but also serving as new 'home' bases from which to engage in circular migration (Hugo 1982).

The culture of mobile boat-dwelling people across the archipelago, comprising diverse congeries of variously named groups known as orang suku laut (sea nomads), also dates back many centuries (Chou 2003). The existence of their far-reaching maritime networks across the archipelago, and beyond, reflects the almost unhampered movement that these people enjoyed historically. As Cynthia Chou (2003) points out, the rise of the nation state led to the progressive peripheralization and impoverishment of the sea nomads. Even today, they travel the seas of the archipelago, challenging the idea of citizenship as defined by bounded territories and guaranteed by a sovereign state (Lowe 2003).

\section{Merantau}

The most widespread mobility tradition across the Indonesian archipelago is called merantau: 'leaving one's cultural territory voluntarily whether for a short or long time, with the aim of earning a living or seeking further knowledge or experience, normally with the intention of returning home' (Naim 1976: 150). ${ }^{4}$ The rantau is about 'foreign spaces that are, at once, unknown and to be discovered yet known, because others, ethnically connected to you, have enabled such spaces to be imagined' (Ali 1996: 428). As Johan Lindquist (2009) observes, the explicit demand to return indicates that merantan is actually about the relationship with 'home' (on the practice of 'return' in other contexts of mobility, see Lulle; Gregorič Bon; Repič, this volume). Kinship and locality remain the principal sources of identification (Naim 1974: 292; Siegel 2000: 56) throughout Indonesia for those who enter the rantau, and it is very bad for the perantau, the one who temporarily moves in order to expand both his (or, increasingly, her) horizons and opportunities, to become 'destitute in rantau' (melarat di rantau), to be lost in rantau, forgotten by those staying home (Mrázek 1994: 10-11).

This culturally-inflected mobility pattern has a long tradition in (western) Sumatra, particularly among the Minangkabau people, who are considered to be among the most mobile of all major ethnic groups in Indonesia (Naim 1974). Their matrilineal social structure 
makes males (who live as guests in the homes of their wives) marginal within society, which led to merantau becoming the norm for young men, with social disapprobation being incurred if they did not conform to this pattern. Unmarried Minangkabau men travelled on the rantau, as part of the adat (customary law), to make their fortunes and feed their spirits, sometimes for long periods. In other words, 'young single men could situate themselves within the statesanctioned role of perantau, or migratory breadwinner, whether or not they actually provided remittances for their families' (Silvey 2000b: 149).

Men living in the rantau who were already established as promising merchants were traditionally considered much more attractive as husbands than young men who were 'left behind' at home. ${ }^{5}$ They typically received handsome dowries from their new in-laws, adding considerable symbolic capital to their bride's family line. The usual length of merantau was anywhere between six months and a year, after which the young men would return to the village with earnings, prestige and tales of the outside world. The stock of experience gained elsewhere helped the village to understand and adapt to the outside world, and the wiser young men, presumably having got the spirit of adventure out of their systems, could settle down into marriage and village life. To a married man, merantau meant a temporary release from two families' conflicting expectations that weighed upon him as a husband and as a member of the maternal family.

Historically, the rantau thus became a space in which the man gained more power than he could have in the matrilineal heartland (Mrázek 1994: 10-11). Among the Minangkabau, merantau is best described as a traditional 'rite of passage' for becoming a man (Kato 1982: 196). Being in the rantau was not only about gaining experience and a form of education, but was also a criterion by which to increase social status, not unlike the European historical 'Grand Tour', a culturally approved trip through Europe for young, educated, wealthy men in the eighteenth and nineteenth centuries, symbolizing the end of their upbringing and giving them the required social and cultural capital for a future as political leaders. Rantan journeys could reach all the way north to the tip of Sumatra, up and down the west coast of the island, to parts of the east coast (including Jambi and almost as far as Medan) and even across the Strait of Malacca to Negeri Sembilan (a Minangkabau colony in peninsular Malaysia) or further. Importantly, 'merantau as a means to avoid being fixed to a particular social location is only possible with on-going exchanges between people separated by physical space' (Ali 1996: 14). The rantau thus 
connotes a realm of imagined familiarity, despite the fact that many who speak of it may never themselves venture into it (cf. Salazar 2011b). This points to the important role undertaken by socially shared cultural imaginaries in making sense of translocal movements (Salazar 2010a; 2011a; 2013).

Among the Minangkabau, merantau clearly functions as an institutionalized cultural complex of circular wandering. However, as Graeme Hugo rightly points out, 'the institutionalization of a particular form of mobility, whether non-permanent or permanent, operates not only on the scale of the ethnic group but also on a regional and local scale' (1982: 68). At the same time, merantau is culturally dependent. This is illustrated by the fact that it has had a historically different meaning in the matrilocal system in Aceh (the far north of Sumatra). There, it served as a strong incentive to go on the 'ranto' as Acehnese men were usually without resources until their parents died (Siegel 2000: 54). According to Acehnese adat, however, men were not allowed to travel too far from their family. Not only did merantau not have the 'rite of passage' characteristics it has elsewhere, it did not necessarily lead to a change in status either. It was merely a way of earning a livelihood. If a man could make a satisfactory independent income, he would simply stay at home.

For the Boyanese, from the tiny island of Bawean, two hundred kilometres off the northeast coast of Java, merantan is a 'cultural ideal' (Vredenbregt 1964: 109). Bawean is known as the 'Island of Women', because almost every household has men working in either Malaysia or Singapore. This labour mobility is a societal rite of passage for young men, dating back to the seventeenth century. The Banjarese people of South Kalimantan have a long history of journeying outside their homelands, too (Hugo 1982). They have the concept of madam, which traditionally meant leaving one's natal village and crossing the sea with the aim of increasing one's wealth within a time period that is not fixed (but which is usually in excess of one year). Madam is used more broadly in contemporary South Kalimantan, encompassing both non-permanent and permanent moves. Many Banjarese engage in circular seasonal mobility associated with trading, especially downriver to the provincial capital of Banjarmasin.

The Iban of Borneo (also known as 'sea Dayaks'), who are spread across the Malaysian-Indonesian border, have been particularly noted for their mobility. The most important traditional form of Iban mobility was restricted to groups of young men in an institution called bejalai. Historically, bejalai, 'to go on journeys with the view 
of acquiring wealth, material goods and social prestige' (Kedit 1993: 3 ), was an important rite of passage for young men: 'Iban values of valour, equality and individualism support bejalai and have made it a viable institution throughout Iban history' (Kedit 1993: 3). These (often adventurous) journeys frequently lasted for several years on end and often extended to the remotest corners of Borneo, and even to Peninsular Malaysia and other islands of Indonesia. The idea was to work, to 'see the world', to have noteworthy experiences and, hopefully, to return with many gifts as well as other visible signs of wealth (to add to the family's collection of heirlooms). This was such an important cultural institution that boys were socialized early in life, mainly through stories, to be predisposed to going away for a few years on bejalai as part of their initiation into adulthood.

Peter Kedit, himself an Iban, recounts how 'cultural heroes in Iban mythology performed triumphant bejalai, undertaking feats which provide both inspiration for and a model of conduct for bejalai aspirants' (Kedit 1993: 11). The success of activities achieved while travelling on bejalai journeys, usually in small groups and under the guidance of recognized leaders, contributed towards a bachelor's status (and was exhibited through tattoos). Although primarily for the purposes of headhunting, the acquisition of trophy heads as evidence of bravery, travelling led to other rewards that enhanced a man's status and his capability of acquiring a spouse. Bejalai in itself has been transformed from headhunting raids into today's labour mobility. Iban people still go abroad to work, as mentioned, but now do so to acquire cash rather than to accrue social prestige. In the 1970s, rural men temporarily migrated to work in logging camps. Construction work in oil palm plantations and in the petrochemical industry came later in the 1980s. For rural women, the economic boom of the late 1980 s and early 1990s caused them to move to urban centres. Bejalai for many Iban turned into pindab (permanent migration) when workers stopped returning home. Bejalai has gradually turned into rural-urban migration, as is characteristic in most developing countries (UNDP 2009) and, as such, it is no longer restricted to men.

In the nineteenth century, the expansion of capitalist markets throughout the archipelago facilitated the rantau, but continued to be associated with particular ethnic groups. By the early twentieth century, however, 'the rantau became a way to learn about the world; for others it was a way of engaging with progressive political forces; and for still others it was an escape from the burden of culture in a matrilineal society in which men were guests' (Lindquist 2009: 29-30). According to Johan Lindquist (2009), merantau has become 
homogenized as a national cultural form, as increasing numbers of Indonesians have been transformed into temporary migrants in search of new forms of life and labour. After independence, mobility increased exponentially across Indonesia and, in the process, 'merantau was unmoored from particular ethnic groups, becoming widely used throughout Indonesia and associated primarily with the new underclass rather than the country's elite' (Lindquist 2009: 30). ${ }^{6}$ The vicissitudes of economics and modernity have changed the practice of merantau. It no longer implies a return to the village and a sharing of experience, but rather an escape from the limited possibilities of village life. In other words, instead of being a circular movement or, in Ingold's (2011) terminology, a kind of 'wayfaring', which strengthens the relationship with the 'homeland', merantau (and its cultural varieties) has increasingly become a one-way, linear journey of migration, wherein the meaning of 'home' has also changed. As a result, many villages have been drained of their young men and, in the cities, one can see groups of unemployed men sitting around smoking, chatting and hoping to find jobs.

Analysing the situation on the island of Sumba, Jill Forshee observes how a haunting tension between moving about and staying put disturbs people who leave the island:

Although travel marks male privilege and a growing worldliness has become a Sumbanese prestige symbol, attachment to ancestral place creates a tension in the wanderings motivated by trade and status seeking. Travel entails tremendous risks, which may result in the worst sort of annihilation-the loss of body and soul ... As long-distance travel has become a regular practice for many (and a symbol of modern mobility), serious perils threaten these ventures. For those removed from their families and protective spirits, potential misfortunes (hanggamar) are causes for anxiety. (Forshee 2000: 24)

Clearly, new forms of mobility have changed the traditional relationship between people and places, and thus also the connection with 'home', both spatially and socially. In the same way that Sarah Green conceptualizes 'Europe', we could argue that home is 'more of a contingent and relative location than it is a fixed place with particular characteristics' (2013: 287-88). The traditional Indonesian practice of merantau illustrates this nicely. Home is a relational concept, built and rebuilt while there, away and upon one's return (cf. Lindquist 2009). This implies that changes to the kind of journeys undertaken, in terms of both time and distance, do alter people's understanding of 'home'. 
Better employment opportunities and wages in neighbouring countries, and a similarity to countries with a Muslim tradition in the case of the Middle East and with shared cultural values and languages in the case of Malaysia, Brunei and Singapore, contributed to the establishment of so-called 'traditional mobility networks' (Spaan 1994: 93). Today, Indonesians are still following these kinds of customary circuits of mobility. Outside influences may have altered the patterns of circulation, but circulation itself has endured. At the same time, 'the notion of timeless movement obscures the political-economic dynamic that produces historically specific dislocations in life chances that motivate international migration, and it accounts for neither increased mobility over the last three decades or so, nor the specificity of flows' (Goss and Lindquist 2000: 398). As Graeme Hugo remarks, 'any close observer of Asia over the last two decades cannot fail to have noticed how international mobility of one kind or another has entered the calculus of choice' for a large number of people (2005: 95). Contemporary transnational mobility in Indonesia, as in areas elsewhere, is thus the outcome of a combination of factors: traditional cultures of mobility, expanding capitalist markets and interventions by the nation state.

The last decades have seen an increase not only in the numbers of Indonesians on the move but also in the types of mobility, which have themselves become more complex and less selective. The forces responsible for this are associated with 'globalization, increased levels of education, proliferation of international media, improved transport systems, and the internationalization of business and labour markets' (Hugo 2005: 94). Merantau certainly remains important, as witnessed by its recurrence as a theme in popular music (Barendregt 2002) and film (Evans 2009). For young adults, the cosmopolitan, distant rantau contains a future that will bring personal and public liberation from the shackles of 'unthinking traditionalism' (Rodgers 1995). Narratives about mobility, however, have moved to the centre of political discourse and claims over historical or contemporary mobilities have turned into a pretext for exclusion. Increasingly, Indonesians are staying in the rantau because of the better opportunities afforded elsewhere and the rantau is coming to span the entire world. As mentioned before, this has implications for the relation between the migratory movements and the meaning of 'home'. 


\section{Brokering Movement and Gender}

Most contemporary border crossings, particularly those related to labour, are closely guarded by nation states (Nyíri 2010). In Indonesia:

For physical mobility to be possible, state bureaucracies have to be approached, evaded or manipulated through links with insiders the various oknums and calur (terms for linkages into bureaucratic offices). Various guards such as pengawal and tai kong assist in crossing boundaries. Many of them have come to play this role by attempting to move out of enclosing spaces themselves, and in the process, acquired the skills to deal with borders, boundaries, categories, documents and policing agents. $(\text { Ali 1996: III })^{7}$

In the case of travels to Saudi Arabia, there is a clear linkage with the religious institution and the Islamic pilgrimage or Hajj. Through their pilgrimages to Mecca, people from the Indonesian archipelago historically established contacts with networks of pilgrim brokers (Arab sheikhs), who made work and travel arrangements for them for employment in Malaya and Sabah via Singapore (Spaan 1994). In other words, the religious routes formed the basis for labour mobility. Singapore was the regional centre for Hajj labour brokers who organized Hajj labour mobilities.

In general, translocal labour mobility in Indonesia has been dependent upon supposedly traditional informal patron-client networks (Rudnyckyj 2004). Brokers usually are (or have been) mobile themselves, and their networks are available to outsiders in exchange for a fee. The brokers' essential attribute, to the agencies for which they recruit prospective workers, is their potential to recruit in their own local environment (where the agencies have no access at all). To the workers, they represent the agency and have contacts with the 'big bosses' far away in Jakarta or abroad, hence, the promise of the big, wide world (which is fed by social imaginaries circulating through old and new media). Yet these brokers remain part of the prospective workers' social networks and are usually trusted by both the 'movers' and their families. Given changes to the global labour market, the relation between broker and worker has become increasingly marked by gender. Within the literature on transnational labour mobility, substantial attention is now being paid to the ways in which female workers experience control over, and restrictions to, their mobility (e.g., Killias 2010). 
Multiple, gendered social differences are reflected in mobility. ${ }^{8}$ Apart from labour mobility, the gendering of movement in general is engrained deeply in archipelagic culture(s). As Jill Forshee writes about the island of Sumba:

The movement of men and women of eastern Sumba reflect social and ideological boundaries and various flows between existential realms ... There is potential power in mobility, in securing or altering one's place in the world by extending influence within it. Yet there is also power in resisting unwanted shifts in location and controlling limits that others might not violate. Adventure threatens to bring pollution or destruction, and human mobility challenges the stability of social life in Sumba. (Forshee 2000: 23-24)

Women's mobility throughout the Indonesian archipelago was traditionally associated with family or marital migration (Williams 2007).

Nowadays, the mobility of women is often still viewed as a disturbance, containing tensions and contradictions that require legitimation. While merantau is culturally considered to be a normal (or even normative) behaviour for men, and constitutive of Indonesian masculine identities (see above), women doing exactly the same are just main-main (drifting, literally: playing) (Silvey 2000a). Thus, the association of men and mobility versus women and immobility and the domestic sphere has a long tradition. However, through time merantan has become something that is of value for (unmarried) young women, too. This has much to do with the feminization of labour in the rantau, beginning in the late 1960s and 1970s. Women now comprise the majority of the migrant workforce, partly because demands from the global labour market tend to channel young, rural Indonesian women into overseas work (e.g., contract domestic work), while preventing men from doing so. The whole machinery involved in organizing Tenaga Kerja Wanita (TKW or overseas female labour force) has also led to the expansion of human trafficking and prostitution (Lindquist 2009).

The recruitment of female workers for overseas labour is largely in the hands of men, usually the husbands, brothers or sons of women who have travelled overseas (Spaan 1994: 103). The social inappropriateness of a woman travelling unescorted into the unknown, along with the cost of travel, prevents women from leaving their villages alone. From the day of their recruitment in the village of origin until their arrival at their employer's home abroad, female transnational workers are escorted by male brokers. As heads of kin and household, men across Indonesia are institutionalized in adat (customary law) to 
control women's mobility by their power over decision making. The fact that women actually travel thousands of kilometres for new job opportunities in the domestic service sector (an estimated 75 per cent of domestic workers are female) does not necessarily challenge the idea that it is men who wield power in unfamiliar realms.

Following a number of problems related to female workers overseas, in 2005 the conservative Indonesian Council of Religious Scholars (Majelis Ulama Indonesia) issued a fatwa (instruction) that prohibits women from working overseas without their mubrim (close male relatives with whom a Muslim woman may travel, e.g. father, uncle, husband, brother or other male relatives). ${ }^{9}$ Such mobility regimes result in particular forms of control over, and protection of, female workers' mobility (cf. Glick Schiller and Salazar 2013). However, producing safety through controlling their mobility can also result in immobility (Kloppenburg and Peters 2012). In the wake of the feminization of long-distance mobility across the whole of Asia, however, brokerage is both increasingly gendering and gendered. As a result of this, a large number of mobility brokers are now women, even if men still appear to be predominant (Lindquist, Xiang and Yeoh 2012).

At the same time, women's mobility in Indonesia does represent a partial break with earlier cultural traditions. Indonesian women's increased access to mobility can be seen as a struggle for new subjectivity (Forshee 2000; Williams 2007). Their translocal movements contest a local femininity, transgressing the cultural association of women with 'home' and are partly an embodied response to the constraints and rigidity of their subject positions and roles at home, as well as to challenges and opportunities presented by globalization. If the women send remittances to their families, or if they invest their incomes in their home villages, their overseas mobility becomes less overtly challenging to the family systems and national economies that they have left behind. However, 'the transnationalization of Indonesian women's migration neither fits neatly into the state's vision of the ideal "family" nor does the spatial mobility of transnational women generally help solidify old versions of national unity' (Silvey 2006: 34). Being transnationally mobile, while still confined in their movement, many female migrant workers end up making journeys that have been characterized as 'confined mobilities' (Kloppenburg and Peters 2012).

Importantly, gender often structures the forms that brokerage takes, because debt, labour rights and visa processes often vary between men and women, particularly with the increasing 
formalization of migration (Lindquist, Xiang and Yeoh 2012). At the same time, mobile workers have become more resourceful in obtaining information through expanded social relationships and new ways of connecting. These networks are essential in empowering the workers when they face difficulties. Women use the possibility of travelling and working abroad to realize, and develop, ideas of how they would like to live in a modern world. In so doing, they combine strategically traditional values with Islamic, state-promoted and 'modern' ones. The TKW, or overseas female labour worker, is seen by the dominant sociocultural ideology as a 'woman out of place': 'a figure whose transnational mobility ... both threatens the national order and promises a way forward' (Barker and Lindquist 2009: 54).

\section{Mobile Tradition and Modernity}

In Indonesia, as elsewhere, contemporary mobilities are informed both by a long tradition (see above) and by more recent imaginaries of what it means to be 'modern'. While the meaning of 'modernity' has been hotly debated across the scholarly spectrum as a contested concept full of ambiguities and tensions, as a social imaginary, it plays a pervasive and powerful role and seems crucial to people's self-understanding and the understanding of their relationship with people and places. In Indonesia, the seductive allure of becoming moderen (modern) is a particular enticement to the young and the upwardly mobile. In a fascinating multi-authored essay entitled Figures of Indonesian Modernity, fourteen anthropologists focus on a series of characters that are pervasive in 'modern' Indonesia. The lead authors define modernity as:

A temporary place holder for the constellation of forces that define the contemporary moment in at least one corner of the world ... [T] his moment is characterized by the pervasive effects of capitalism and commodification, a deep ambivalence about older figures of authority, and the emergence of new claims to authority grounded in new media. (Barker and Lindquist 2009: 38)

Interestingly, some of the figures covered in this essay are directly related to border-crossing mobilities: the TKW, or overseas female labour migrant, who embodies the contradictions of class and gender mobility (by Silvey); the petugas lapangan, or field agent, who functions as an informal labour recruiter for transnational migrants (by Lindquist); and Pak Haji, or Mr Hajj, who wears the white cap that 
proclaims he has made the pilgrimage to Mecca (by Darmadi). This illustrates how modernity is linked to 'moving forward' in both physical and imaginative ways (cf. Cresswell 2006). ${ }^{10}$ The idea of modernity commonly includes two distinguishing (and almost normative) characteristics: (1) a break from an out-of-date past and (2) progress into an improved future. The case of Indonesia illustrates the imaginary aspect of this idea because culturally-inflected mobilities, such as merantau, remain important while the dream of more social mobility is unattainable for the majority of the population.

While older people often connect modernity to orthodox Islam (as opposed to premodern spirit beliefs), the younger generations in Indonesia seem to be adhering to a more secular kind of modernity. For them, there are also links between becoming Indonesian, increased identification with the Muslim world, becoming urban, becoming 'modern' and becoming wealthy. People and places can, at the same time, be trapped in limbo, neither 'traditional' nor 'modern', not progressing on a straight path from the former to the latter, a state that Suzanne Brenner (1998) describes as the 'unmodern', haunted by the spectre of past modernities and their failure.

The imaginative aspects of what it means to be 'modern' are reflected in the images of technological mobility that the term evokes. ${ }^{11}$ In Indonesia, the idea of becoming 'modern' is correlated with the use of new information and communication technologies. The mobile phone is not merely a tool for communication; it is also an emblematic cultural artefact infused with symbolic meaning and representational value that plays a role in the construction of 'modern' subjectivities. The rise of new media in Indonesia, including online social media networks, is embedded in a narrative of modernity that shapes how Indonesians use and understand these technologies. Changes in the media landscape, combined with political upheaval in the late 1990s, prepared the ground for the reception and appropriation of the mobile phone as constitutive of a 'mobile modernity' (Barendregt 2008). In this modernity, people are free to move corporeally, socio-economically and imaginatively. Their imaginaries draw upon (mostly) imagined mobilities in which they, too, are 'flexible citizens' (Ong 1999). In other words, 'modernity has become equivalent to mobility' (Barendregt 2008: 160). However, for most people, this mobility has to be qualified as 'limited mobility', because even the mobile technologies to which they have access are constrained by a particular time and space. This reduced technological access contextualizes and conditions their geographical and social mobilities. 
'Modern subjects' are above all mobile urbanites, in stark contrast with the orang kampung (rural dwellers, understood to be 'country bumpkins' or 'hicks'). ${ }^{12}$ In other words, modernity in Indonesia is not only associated with technology but also with places. There is a clear hierarchy of which places are seen as more 'modern', ranging from towns to provincial capitals, and from Jakarta to global cities such as Singapore and Hong Kong (where many Indonesian migrants work). There is a marked contrast, however, between imagining modernity and making people experience attachment to their new (urban) settings. For most rural-urban migrants, their kampung halaman (ethnic 'homeland') remains the place where they feel they belong (Thompson 2002). That is why many migrants deem it important to remain in close contact with their home base, either through visits (physical movement) or through new mobile technologies (imaginary mobility). Moreover, many of the urban settlements where migrants dwell mimic tangible physical elements of the rural kampung environment (Somantri 1995). As Vickers (2004) writes:

Indonesian cities ... are impermanent sites of modernity. Cities contain nodes of liminality, of which kampungs are the main focus for movement. Those who can raise the fares to travel move with contact names and addresses of people they will link up to in an urban kampung made up, one hopes, of people from one's village of origin. People do not think of themselves as "migrants" necessarily, because the village is always "home", and in the process of travel you try to keep up those village links. (Vickers 2004: 313-14).

\section{Conclusion}

Questions about mobility take on particular meanings in specific political-economic contexts that have produced those movements and discourses (Ford and Lyons 2006). Though few regions have been able to match Southeast Asia's ethnic diversity, even fewer have been able to match its histories of movement (Tagliacozzo 2009). As Vickers argues:

The study of Southeast Asia needs to take account of mobility across the region and its various cultural and material manifestations. If we assume that mobility is an inherent part of Southeast Asian states and societies, then we can first assume that people moved and brought elements of culture backwards and forwards; and, second, that wider patterns of fluidity are built into local epistemology and ontology. (2009: 70) 
Mobility is certainly central to the lives of many people in Indonesia (for a similar account in the Albanian context, see Gregoric Bon, this volume). However, as described in this chapter, Indonesian patterns of human movement have undergone dynamic changes, linked to various regional political events and circumstances. In the past, indigenous patterns of circular mobility tended to revolve around trade networks and seasonal subsistence but, with the expansion of European colonialism and global capitalism, mobility has shifted to accommodate and deal with these changes. In many cases, externally generated changes reinforced traditional forms of mobility, such as merantau, and added new ones.

One gets a good impression of the massiveness of Indonesian interisland mobility at the end of the Muslim fasting month, Ramadan, when millions of Indonesians (not Muslims exclusively) criss-cross the archipelago to return 'home' (pulang kampung). Many spent most of their money, painstakingly earned during the year, in order to have some quality time together with their family (particularly their parents). This mass homecoming practice is called mudik Lebaran. ${ }^{13}$ This is not merely a religious or spiritual affair, but also an economic and cultural phenomenon. Typically, it involves travel from centres of employment or education - cities - to rural villages or provincial towns where people have left their families behind. The ritual typically manifests itself in traffic chaos.

Mudik Lebaran shows the lasting importance of family networks and 'home', as I have discussed in the context of merantau. The rich tradition of merantau, or travelling to gain experience (at different levels), serves to illustrate that translocal border crossings are not generally made with the intention of uprooting people, but are experienced by both 'movers' and 'stayers' as incomplete and openended. Because merantan is culturally institutionalized, it assumes an element of circularity, in that leaving and returning are equally encouraged. ${ }^{14}$ Home and the feeling of belonging are imaginatively constructed through movement (cf. the introduction to this volume). Most Indonesians are part of this mobility, whether personally or through the back and forth movements of relatives or significant others. Culturally rooted understandings of geographical mobility, such as merantau, are as relevant as real physical movements in attempting to explain the meaning of (im)mobility (Salazar and Smart 2011). Merantan is a process that is strongly connected to cultural and kinship values.

The example of merantau shows tradition and institutionalization can also encourage stability and lack of mobility. The mobility of 
women was hindered for a long time, because cultural norms constrained their individual freedom. However, a sort of female rantan emerged in the late twentieth century and continues today. The traditional merantan experience speaks of travels that draw people closer to, rather than pushing them away from, 'home'. However, the locally-rooted meanings of merantau mobility have changed in response to the rapidly changing wider economic context. The process of merantau is increasingly changing into migration, i.e., to permanent settlement elsewhere. While many find the reality of life in the rantau vastly different to how they imagined it, they end up staying for a variety of reasons (Rodgers 1995).

The changing practice of merantau is accompanied by shifts in the meaning of 'home', from a lived to a culturally constructed space (cf. Gregorič Bon, this volume). For many Indonesians, home is no longer referring to a fixed locale (cf. Gregorič Bon; Lulle; Repič, this volume), even though people often define it like that when making claims of rootedness and belonging. It seems that the contemporary meaning of home merges mobility and immobility at the same time, exemplifying Green's (2013) 'relative location'. As suggested in the introduction to this volume, besides people, places such as home also shift their location. While merantau has evolved from circular mobility to more permanent migration, modern travelling and communication technologies have decreased the geographical distance with the kampung halaman (homeland). This allows Indonesian migrants to keep in touch with their native 'home' base while, at the same time, trying to construct, culturally, a kampung-like life in urban settings. So, while many Indonesian migrants have left their kampung halaman (some forever), they have not abandoned (the imaginary of) the(ir) kampung.

Noel B. Salazar is a Research Professor in anthropology at the University of Leuven, Belgium. He is editor of the Worlds in Motion (Berghahn) and Anthropology of Tourism (Lexington) book series, co-editor of various edited volumes and special issues, and author of numerous peer-reviewed articles and book chapters on mobility and travel. He is vice-president of the International Union of Anthropological and Ethnological Sciences, past president of the European Association of Social Anthropologists and founder of AnthroMob, the EASA Anthropology and Mobility Network. In 2013, Salazar was elected as member of the Young Academy of Belgium. 


\section{Notes}

1. I carried out ethnographic fieldwork and archival research in Indonesia in 2011 (supplemented with data from previous research in the country since 2000).

2. I use the notion '(im)mobility' to critique the dichotomy between mobility and immobility that characterizes some of the scholarship. Mobility and immobility are two sides of the same coin. They should only be separated for analytical purposes (cf. Salazar and Smart 2011).

3. The rich vocabulary people have developed to talk about movement is evidence of this. Jill Forshee, for instance, describes the different terms that exist in eastern Sumbanese: palaku connotes journeying, danggangu applies to wide-ranging travel for the purposes of trade, whereas mbawa implies travelling about for pleasure, usually over short distances (2000: 210).

4. The word rantan refers to the (often adventurous) geographical, social and moral realm of journeying outside the ethnic 'homeland' (kampung halaman). It was originally limited in meaning to the coast to which people travelled from the hinterland, but the notion acquired additional meanings of travelling upriver, studying abroad, wandering and bordercrossing mobility in general.

5. In this context, the idea of being 'left behind' has two related meanings: (1) remaining in the village and (2) not 'progressing' or becoming 'modern'.

6. At the same time, the ratio from Sulawesi remains at a higher level, suggesting that the cultural orientation to merantan continues to influence mobility from this area.

7. Oknum is a euphemism for rogue elements in the Indonesian police and the militaristic preying on migrant workers. Calur or calo are the words used to denote employment brokers, the line between informal and legal variants being difficult to draw. Pengawal (literally 'body guard') and tai kong are terms for migrant smugglers, similar to 'snakeheads' (smuggling Chinese people across the globe) and 'coyotes' (smuggling people across the U.S.-Mexico border).

8. Anna Tsing, for example, has noted that in the Meratus region of Kalimantan a travelling woman is considered to be a 'disorderly' woman (1993: 219). Jill Forshee describes how the cultural ideals of masculine and feminine mobility across Indonesia are even visible in traditional wear: '[f]ollowing customary poise, women throughout Indonesia should be slow and graceful (balus), and clothing accentuates their movements. Most traditional wear inhibits long strides affecting a woman's poise. Some have interpreted this as constraining women's mobility in a larger sense' (2006: 142).

9. According to Islamic law, mubrim (or mabram) indicates a degree of consanguinity that renders marriage impossible, but gives a man and 
a woman the right of association. Theoretically, a Muslim woman's mubrim forms the group of escorts with whom she is permitted to travel.

10. For the multiple links scholars have made between modernity and mobility, see the work of, among others, Arjun Appadurai (1996), Marc Augé (1995), Zygmunt Bauman (2000), Walter Benjamin (1999), Tim Cresswell (2006), and Dean MacCannell (1999).

11. Technologies, as emblems of modernity and mediators of novel kinds of social relations and imaginaries that gave rise to national communities, played a key role in the entanglement of nation and modernity (Anderson 1991). Modernity and Indonesian nationalism, for instance, were almost indistinguishable for most of the first half of the twentieth century. However, modernity has always been 'at large' (Appadurai 1996), exceeding the boundaries of the nation, even as the desire to participate in global modernity was itself a force animating the formation of the Indonesian national community.

12. This becomes evident when labour migrants return to their village of origin with some savings, a new look and, above all, 'a body politics (speech and deportment) that speaks of experience of modernity and a shrugging-off of the label "orang kampung”' (Elmhirst 2007: 232).

13. Lebaran is an Indonesian word for the Arabic Eid al-Fitr (the Sugar Feast, marking the end of Ramadan). Mudik is derived from udik, a noun denoting someone from a remote area, as well as a humble or innocent person. By adding the consonant ' $m$ ' (mudik), it lexically comes to mean travelling from the city to the village, from a 'modern' place to a remote and less developed place.

14. Circular mobility is generally community-based and occurs within the most 'customary' societies: the depth of traditional culture explains the strong linkages with the territories of origin and the cohesiveness of group structures.

\section{References}

Ali, M.M. 1996. 'Ethnic Hinterland. Contested Spaces between Nations and Ethnicities in the Lives of Baweanese Labor Migrants', Ph.D. Dissertation. Cambridge, MA: Harvard University.

Anderson, B.R. 1991. Imagined Communities. Reflections on the Origin and Spread of Nationalism. $2^{\text {nd }}$ ed. New York: Verso.

Appadurai, A. 1996. Modernity at Large. Cultural Dimensions of Globalization. Minneapolis: University of Minnesota Press.

Augé, M. 1995. Non-Places. Introduction to an Anthropology of

Supermodernity, trans. John Howe. London: Verso. 
Barendregt, B. 2002. 'The Sound of "Longing for Home". Redefining a Sense of Community through Minang Popular Music', Bijdragen tot de Taal-Land-en Volkenkunde 158(3): 411-50.

- 2008. 'Sex, Cannibals, and the Language of Cool. Indonesian Tales of the Phone and Modernity', Information Society 24(3): 160-70.

Barker, J. and J. Lindquist. 2009. 'Figures of Indonesian Modernity', Indonesia 87: 35-72.

Bauman, Z. 2000. Liquid Modernity. Cambridge: Polity Press.

Bedford, R. 1973. New Hebridean Mobility. A Study of Circular Migration. Canberra: Australian National University.

Benjamin, W. 1999. The Arcades Project. Cambridge: Belknap Press.

Bonnemaison, J. 1984. 'The Tree and the Canoe. Roots and Mobility in Vanuatu Societies', Pacific Viewpoint 25(2): 117-51.

Brenner, S.A. 1998. The Domestication of Desire. Women, Wealth, and Modernity in Java. Princeton: Princeton University Press.

Chapman, M. and R.M. Prothero (eds). 1985. Circulation in Population Movement. Substance and Concepts from the Melanesian Case. London: Routledge.

Chou, C. 2003. Indonesian Sea Nomads. Money, Magic, and Fear of the Orang Suku Laut. London: Routledge Curzon.

Cresswell, T. 2006. On the Move. Mobility in the Modern Western World. New York: Routledge.

Elmhirst, R. 2007. 'Tigers and Gangsters. Masculinities and Feminised Migration in Indonesia', Population, Space and Place 13(3): 225-38.

Evans, G. 2009. Merantau. Jakarta: Pt. Merantau Films.

Ford, M. and L. Lyons. 2006. 'The Borders Within. Mobility and Enclosure in the Riau Islands', Asia Pacific Viewpoint 47(2): 257-71.

Forshee, J. 2000. Between the Folds. Stories of Cloth, Lives, and Travels from Sumba. Honolulu: University of Hawai'i Press.

. 2006. Culture and Customs of Indonesia. Westport: Greenwood Press.

Glick Schiller, N. and N.B. Salazar. 2013. 'Regimes of Mobility across the Globe', Journal of Ethnic and Migration Studies 39(2): 183-200.

Goss, J. and B. Lindquist. 2000. 'Placing Movers. An Overview of the AsianPacific Migration System', The Contemporary Pacific 12(2): 385-414.

Green, S. 2013. 'Replacing Europe', in R. Fardon, T.H. Marchand, C. Shore, V. Strang, R. Wilson and M. Nuttall (eds), The Sage Handbook of Social Anthropology. Thousand Oaks: Sage, pp 286-307.

Hugo, G.J. 1982. 'Circular Migration in Indonesia', Population and Development Review 8(1): 59-83.

- 2005. 'The New International Migration in Asia. Challenges for Population Research', Asian Population Studies 1(1): 93-120.

Ingold, T. 2011. Being Alive. Essays on Movement, Knowledge and Description. London: Routledge.

Kato, T. 1982. Matriliny and Migration. Evolving Minangkabau Traditions in Indonesia. Ithaca: Cornell University Press. 
Kedit, P.M. 1993. Iban Bejalai. Kuala Lumpur: Ampang Press.

Killias, O. 2010. “"Illegal” Migration as Resistance. Legality, Morality and Coercion in Indonesian Domestic Worker Migration to Malaysia', Asian Journal of Social Science 38(6): 897-914.

Kloppenburg, S. and P. Peters. 2012. 'Confined Mobilities. Following Indonesian Migrant Workers on Their Way Home', Tijdschrift voor Economische en Sociale Geografie 103(5): 530-41.

Lindquist, J.A. 2009. The Anxieties of Mobility. Migration and Tourism in the Indonesian Borderlands. Honolulu: University of Hawai'i Press.

Lindquist, J., B. Xiang and B.S.A. Yeoh. 2012. 'Opening the Black Box of Migration. Brokers, the Organization of Transnational Mobility and the Changing Political Economy in Asia', Pacific Affairs 85(1): 7-19.

Lowe, C. 2003. 'The Magic of Place. Sama at Sea and on Land in Sulawesi, Indonesia', Bijdragen tot de Taal-Land-en Volkenkunde 159(1): 109-33.

MacCannell, D. 1999. The Tourist. A New Theory of the Leisure Class. Revised ed. Berkeley: University of California Press.

Mrázek, R. 1994. Sjabrir. Politics and Exile in Indonesia. Ithaca: Southeast Asia Program Publications.

Naim, M. 1974. 'Merantau. Minangkabau Voluntary Migration', Ph.D. Dissertation. Singapore: National University of Singapore.

- 1976. 'Voluntary Migration in Indonesia', in D. Kubát and A.H. Richmond (eds), Internal Migration. The New World and the Third World. Beverly Hills: Sage, pp. 148-83.

Nyíri, P. 2010. Mobility and Cultural Authority in Contemporary China. Seattle: University of Washington Press.

Ong, A. 1999. Flexible Citizenship. The Cultural Logics of Transnationality. Durham: Duke University Press.

Rodgers, S. (ed.). 1995. Telling Lives, Telling History. Autobiography and Historical Imagination in Modern Indonesia. Berkeley: University of California Press.

Rudnyckyj, D. 2004. 'Technologies of Servitude. Governmentality and Indonesia Transnational Labor Migration', Anthropological Quarterly 77(3): 407-34.

Salazar, N.B. 2010a. Envisioning Eden. Mobilizing Imaginaries in Tourism and Beyond. Oxford: Berghahn.

- 2010b. 'Towards an Anthropology of Cultural Mobilities', Crossings. Journal of Migration and Culture 1(1): 53-68.

- 2011a. 'The Power of Imagination in Transnational Mobilities', Identities. Global Studies in Culture and Power 18(6): 576-98.

- 2011b. 'Tanzanian Migration Imaginaries', in R. Cohen and G. Jónsson (eds), Migration and Culture. Cheltenham: Edward Elgar, pp. 673-87.

. 2013. 'Imagining Mobility at the "End of the World"', History and Antbropology 24(2): 233-52. 
Salazar, N.B., and A. Smart. 2011. 'Anthropological Takes on (Im)Mobility. Introduction', Identities. Global Studies in Culture and Power 18(6): i-ix.

Siegel, J.T. 2000. The Rope of God. Ann Arbor: University of Michigan Press.

Silvey, R.M. 2000a. 'Diasporic Subjects. Gender and Mobility in South Sulawesi', Women's Studies International Forum 23(4): 501-15.

- 2000b. 'Stigmatized Spaces. Gender and Mobility under Crisis in South Sulawesi, Indonesia', Gender, Place E Culture 7(2): 143-61.

- 2006. 'Consuming the Transnational Family. Indonesian Migrant Domestic Workers to Saudi Arabia', Global Networks 6(1): 23-40.

Somantri, G.R. 1995. Looking at the Gigantic Kampung. Urban Hierarchy and General Trends of Intra-City Migration in Jakarta. Bielefeld: Universität Bielefeld.

Spaan, E. 1994. 'Taikongs and Calos. The Role of Middlemen and Brokers in Javanese International Migration', International Migration Review 28(1): 93-113.

Tagliacozzo, E. 2009. 'Navigating Communities. Race, Place, and Travel in the History of Maritime Southeast Asia', Asian Ethnicity 10(2): 97-120.

Thompson, E.C. 2002. 'Migrant Subjectivities and Narratives of the "Kampung” in Malaysia', Sojourn. Journal of Social Issues in Southeast Asia 17(1): 52-75.

Tirtosudarmo, R. 2009. 'Mobility and Human Development in Indonesia', Human Development Reports Research Paper. New York: United Nations Development Programme.

Tsing, A.L. 1993. In the Realm of the Diamond Queen. Marginality in an out-of-the-Way Place. Princeton: Princeton University Press.

UNDP. 2009. Human Development Report 2009. Overcoming Barriers. Human Mobility and Development. New York: United Nations Development Program.

Vickers, A. 2004. 'The Country and the Cities', Journal of Contemporary Asia 34(3): 304-17.

- 2009. 'Southeast Asian Studies after Said', Arts. The Journal of the Sydney University Arts Association 31: 58-72.

Vredenbregt, J. 1964. 'Bawean Migrations', Bijdragen tot de Taal-, Land-en Volkenkunde 120(1): 109-39.

Williams, C.P. 2007. Maiden Voyages. Eastern Indonesian Women on the Move. Singapore: Institute of Southeast Asian Studies.

Wolters, O.W. 1999. History, Culture, and Region in Southeast Asian Perspectives. Ithaca: Southeast Asia Program Publications, Cornell University. 